\title{
EDITORIAL
}

\section{NOVAS CONQUISTAS PARA A FMVZ}

Esse número da Revista Veterinária e Zootecnia está sendo editado em um momento que recebemos o resultado da avaliação da CAPES referente ao quadriênio 2013-2016, dos Programas de Pós Graduação do Brasil. Aproveitamos, portanto, para agradecer a todos os envolvidos com o Programa de Medicina Veterinária nível de Mestrado e Doutorado pela obtenção do conceito 6. Os docentes do Programa, os seus alunos e equipe técnica-administrativa, que tanto contribuíram para esse resultado.

Resultado como esse mostra o potencial da FMVZ que tem outros Programas em Pós-Graduação todos muito bem conceituados. Dessa forma, quem ganha é a nossa Faculdade que acumula índices importantes para o ranking de avaliação das Universidades brasileiras e a nível mundial. Como editor da Revista e coordenador do referido Programa, tenho muito a agradecer e também dizer que nossas responsabilidades aumentam e que temos que trabalhar com novas métricas de acordo com as exigências da CAPES. Obrigado.

O presente número da Revista Veterinária e Zootecnia traz artigos interessantes inéditos, contribuindo com o desenvolvimento científico em diferentes áreas do conhecimento. Como artigos de revisão: Mecanismos de ação dos principais antioxidantes utilizados na criopreservação espermática de garanhões; Colheita fracionada e seus principais benefícios na criopreservação do sêmen de garanhões; Acessórios de imobilização e proteção utilizados na radioterapia de pequenos animais; Principais patógenos entéricos de origem bacteriana e parasitária, de potencial zoonótico, em gatos domésticos; Capacidade de ligação dos espermatozoides do epidídimo de equinos às células da tuba uterina cultivadas in vitro - Revisão de Literatura; Principais micotoxicoses em suínos. Os relatos de caso: Tumor venéreo transmissível metastático em canino - Relato de Caso; Sepsis in a dog with chronic kidney disease submitted to peritoneal dialysis; Correção de estenose uretral após uretrostomia em gato - Relato de Caso; Exugunlation followed by fracture and avulsion of the distal phalanx in mare. Os artigos originais: Caracterização do sistema de produção caprino e ovino na região Sul do Estado do Maranhão, Brasil; Utilização da ultrassonografia transabdominal para auxilio propedêutico em equinos com síndrome cólica: Relato de Casos; Laserterapia para tratamento de tendinopatia induzida em ratos Wistar: estudo histomorfométrico; Análise comparativa das leis vigentes para a produção artesanal de leite de cabra no Estado de São Paulo; Influência da marcha sobre o eritrograma em equinos da raça Mangalarga Marchador; pHmetria esofágica em cães; Cipionato de estradiol e benzoato de estradiol em protocolos de inseminação artificial em tempo fixo em novilhas mestiças; Desenvolvendo competências na aprendizagem de estudantes de medicina veterinária; Prevalência de alterações hepáticas em bovinos abatidos em matadouro-frigorífico do município de Presidente Prudente, Estado de São Paulo; Monitoramento do vírus da raiva em diferentes espécies de morcegos em Maringá, Sul do Brasil.

Prof. Helio Langoni Editor-Chefe 